\title{
Simple Method of Purification of Humic Acid isolated from Press mud
}

\author{
Shreelatha $^{1}$, S. N. Bhat ${ }^{*}$, S.R. Balanagoudar ${ }^{1}$, R.V. Beladhadi ${ }^{1}$, \\ Satyanarayana $\operatorname{Rao}^{2}$ and M.V. Ravi ${ }^{1}$ \\ ${ }^{1}$ Department of Soil Science and Agril. Chemistry, University of Agricultural Sciences, \\ Raichur- 584 104(Karnataka), India \\ ${ }^{2}$ Department of Agronomy, University of Agricultural Sciences, \\ Raichur- 584 104(Karnataka), India \\ *Corresponding author
}

Keywords

Humic acid, press mud, purification

\section{Article Info}

Accepted:

15 December 2019 Available Online: 20 January 2020
A study on purification of humic acid (HA) isolated from press $\operatorname{mud}(\mathrm{PM})$ was conducted at Organic Farming Research Institute( OFRI), UAS, Raichur during 2017-18 with distilled water as a purifying agent in the place of HCl-HF mixture to purify isolated HA from press mud. The conventional procedure makes use of mineral acids and dialysis step. Standard procedures were used to extract and fractionate HA from press mud. The extracted HA was purified by suspending the $\mathrm{HA}$ in $50 \mathrm{ml}$ of distilled water, centrifuged for one hour at an interval of 15 minutes; the supernatant solution was analyzed for $\mathrm{K}^{+}, \mathrm{Na}^{+}$and $\mathrm{Ca}+\mathrm{Mg}$ by Flame Photometer and Versanate titration methods, respectively. The suspension left over after centrifugation was purified $\mathrm{HA}$ which was oven dried at $40{ }^{\circ} \mathrm{C}$ to a constant weight. Washing of HA for 4 consecutive times (15 min for each washing) reduced the ash (mineral matter) content of the HA to an acceptance level of 2 per cent. This finding was associated with significant decrease in content of $\mathrm{K}^{+}, \mathrm{Na}^{+}$and $\mathrm{Ca}+\mathrm{Mg}$ with increasing washing time. This observation also suggests that the distilled water used during the purification process served as Bronsted-Lowry acid thereby donating more $\mathrm{H}^{+}$which may have replaced some of $\mathrm{K}^{+}, \mathrm{Na}^{+}$and $\mathrm{Ca}+\mathrm{Mg}$ at the exchange sites of the HA. Humic acids isolated from press mud can effectively be purified within one hour using distilled water.

\section{Introduction}

The processes involved in isolation of Humic Acid (HA) from press mud were extraction, fractionation and purification. Each of these processes is laborious and time consuming.
The usually time required for HA extraction is 24 hours. It takes between 1-7 days to purify HA; fractionation time usually ranges between 12 and 24 hours. Recently, Susilawati et al., managed to reduce fractionation time to two hours in case of HA 
isolated from Hemists peat soil. The purification process of HA involves the use of expensive chemicals such as hydrochloric acid or sulphuric acid as well as hydrogen fluoride. The purification process also employs an expensive process called dialysis. Till date, not much attempt has been made to address the aforementioned problems associated with HA purification particularly those isolated from press mud.

\section{Materials and Methods}

A laboratory experiment was carried out during 2017-18 at Organic Farming Research Institute, Main Agricultural Research Station, UAS, Raichur to know whether distilled water can effectively be used as purifying agent in purification of humic acid and its effect on ash content. The experiment was conducted in Two Factorial Completely Randomized Design (CRD) with different extraction (4, 8, $12,16,20 \& 24 \mathrm{hrs}$ ) and fractionation periods (3, 6,9,12,15,18,21\& $24 \mathrm{hrs})$, which were replicated three times.

The HA extraction was carried out as per the methods outlined by Stevenson (1994) with some modifications. Twenty grams (dryweight basis) of organic source (presssmud) samples were placed into polyethylene conical flask and $200 \mathrm{ml}$ of $0.5 \underline{\mathrm{N}} \mathrm{KOH}$ solution was added and the bottles were closed tightly with rubber cork. The samples were shaken at room temperature on a mechanical shaker at $125 \mathrm{rpm}$ for $4,8,12,16$, 20 and 24 hours. Samples were equilibrated at different fractionation periods, viz; $3,6,9,12,15,18,21$ and 24 hours. The HA samples were purified with distilled water using centrifuge at $2000 \mathrm{rpm}$ at an interval of 15 minutes. Similar procedure was repeated four times. Then, the HA was collected using a spatula and oven dried at $40{ }^{\circ} \mathrm{C}$ until constant weight was attained. The HA yield obtained was expressed as the percentage of weight of raw material used (Kasim, 2008). Ash content of HA was determined by combusting the HA at $700^{\circ} \mathrm{C}$ as described by Hesse (1994). The concentrations of $\mathrm{K}^{+}, \mathrm{Na}^{+}$and $\mathrm{Ca}+\mathrm{Mg}$ present in supernatant solution was determined by flame photometer and versanate titration methods, respectively ( Jackson, 1973).

\section{Results and Discussion}

The HA extracted from press mud at different extraction and fractionation periods was purified with distilled water and finally ash content in the dried HA was estimated. As per the procedure given by Stevenson and earlier investigations, the extracted $\mathrm{HA}$ will be purified with $\mathrm{HCl}-\mathrm{HF}$ mixture and subjected to dialysis. But in present investigation, instead of $\mathrm{HCl}-\mathrm{HF}$ mixture and dialysis, distilled water was used as a purifying agent.

\section{Effect of extraction and fractionation periods on ash content}

The extracted HA was washed with distilled water for 4 times in 15 minutes interval. At different extraction periods ( 4 to $24 \mathrm{hrs}$ ), the ash content of the HA remained to be non significant and ash content varied from 1.83 to 2.08 per cent indicating that at all extraction periods the ash content of the HA was almost 2.0 per cent (Table.1). There was a significant influence of fraction periods on the ash content of HA. Significantly higher ash content was recorded with fractionation period of 3 hours $(2.33 \%)$ and the lowest ash content of $(1.39 \%)$ was occurred with fractionation time of 24 hours. The low mineral content obtained at 24 hours of fractionation periods is attributed to better replacement of $\mathrm{K}^{+}$and other ions at exchange sites of humic acid with $\mathrm{H}^{+}$ions during equilibration. These liberated ions from exchangeable sites are further removed during purification with distilled water (Fig.1\&2). 
Table.1 Ash content of humic acid derived from press mud at different extraction and fractionation periods

\begin{tabular}{|c|c|c|c|c|c|c|c|c|c|}
\hline \multicolumn{10}{|c|}{ Ash content (\%) } \\
\hline $\begin{array}{c}\text { Extraction } \\
\text { period } \\
(\mathrm{hrs})\end{array}$ & $\mathbf{F}_{3}$ & $F_{6}$ & $\mathbf{F}_{9}$ & $F_{12}$ & $\mathbf{F}_{15}$ & $\mathbf{F}_{18}$ & $\mathbf{F}_{21}$ & $\mathbf{F}_{24}$ & Mean \\
\hline $\mathbf{E}_{4}$ & 2.0 & 1.67 & 1.67 & 2.66 & 1.66 & 2.0 & 1.67 & 1.67 & 1.88 \\
\hline $\mathbf{E}_{8}$ & 2.0 & 2.0 & 2.0 & 1.0 & 2.0 & 2.0 & 2.0 & 2.0 & 1.88 \\
\hline $\mathbf{E}_{12}$ & 2.0 & 1.0 & 2.66 & 2.66 & 2.0 & 1.67 & 2.67 & 1.0 & 1.96 \\
\hline $\mathbf{E}_{16}$ & 3.0 & 1.67 & 2.0 & 2.0 & 2.0 & 2.67 & 1.67 & 1.67 & 2.08 \\
\hline $\mathbf{E}_{20}$ & 2.0 & 2.0 & 2.0 & 1.67 & 2.0 & 2.0 & 2.0 & 1.00 & 1.83 \\
\hline $\mathbf{E}_{24}$ & 3.0 & 1.67 & 2.0 & 1.67 & 2.0 & 2.67 & 2.0 & 1.00 & 2.00 \\
\hline Mean & 2.33 & 1.67 & 2.06 & 1.94 & 1.94 & 2.17 & 2.0 & 1.39 & \\
\hline \multicolumn{3}{|l|}{ Factors } & \multicolumn{4}{|c|}{ C.D (0.05) } & \multicolumn{3}{|c|}{ S. Em. \pm} \\
\hline \multicolumn{3}{|l|}{ Factor $(\mathbf{E})$} & \multicolumn{4}{|c|}{ NS } & \multicolumn{3}{|c|}{0.13} \\
\hline \multicolumn{3}{|l|}{ Factor (F) } & \multicolumn{4}{|c|}{0.406} & \multicolumn{3}{|c|}{0.14} \\
\hline \multicolumn{3}{|l|}{ Factor ( EXF) } & \multicolumn{4}{|c|}{0.994} & \multicolumn{3}{|c|}{0.35} \\
\hline
\end{tabular}

E: Different extraction periods $(4,8,12,16,20$ and 24 hours $)$

F: Different fractionation periods $(3,6,9,12,15,18,21$ and 24 hours $)$

Table.2 Content of potassium in the supernatant solution $(\mathrm{ppm})$ during purification of humic acid from press mud at 24 hours of extraction

\begin{tabular}{|c|c|c|c|c|c|}
\hline At 24 hrs extraction & \multicolumn{3}{|c|}{ Potassium content (ppm) } \\
\hline $\begin{array}{c}\text { Fractionation periods( } \\
\text { hrs) }\end{array}$ & $\begin{array}{c}\mathbf{1}^{\text {st }} \\
\text { wash }\end{array}$ & $\begin{array}{c}\mathbf{2}^{\text {nd }} \\
\text { wash }\end{array}$ & $\begin{array}{c}\mathbf{3}^{\text {rd }} \\
\text { wash }\end{array}$ & $\mathbf{4}^{\text {th }}$ wash & \% decrease in content in $\mathbf{4}^{\text {th }}$ wash over \\
\hline $\mathbf{3}$ & 53.36 & 40.40 & 40.86 & 24.98 & 53.2 \\
\hline $\mathbf{6}$ & 61.79 & 55.95 & 51.08 & 42.84 & 30.7 \\
\hline $\mathbf{9}$ & 74.94 & 53.14 & 48.99 & 37.31 & 50.2 \\
\hline $\mathbf{1 2}$ & 72.41 & 56.10 & 53.81 & 51.09 & 29.4 \\
\hline $\mathbf{1 5}$ & 67.00 & 59.95 & 59.06 & 50.43 & 24.7 \\
\hline $\mathbf{1 8}$ & 72.93 & 63.13 & 54.63 & 48.28 & 33.8 \\
\hline $\mathbf{2 1}$ & 85.16 & 72.50 & 64.89 & 55.15 & 35.2 \\
\hline $\mathbf{2 4}$ & 97.21 & 90.15 & 65.96 & 57.45 & 40.9 \\
\hline
\end{tabular}


Table.3 Content of sodium in the supernatant solution ( $\mathrm{ppm}$ ) during purification of humic acid from press mud at 12 hours of extraction

\begin{tabular}{|c|c|c|c|c|c|}
\hline At 24 hours of extraction & \multicolumn{4}{|c|}{ Sodium content (ppm) } \\
\hline $\begin{array}{c}\text { Fractionation periods( } \\
\text { hrs) }\end{array}$ & $\mathbf{1}^{\text {st }}$ wash & $\mathbf{2}^{\text {nd }}$ wash & $\mathbf{3}^{\text {rd }}$ wash & $\mathbf{4}^{\text {th }}$ wash & \% decrease in content in $\mathbf{4}^{\text {th }}$ wash over \\
\hline $\mathbf{3}$ & 5.93 & 4.38 & 3.88 & 3.49 & 41.1 \\
\hline $\mathbf{6}$ & 6.75 & 6.13 & 5.00 & 3.46 & 48.7 \\
\hline $\mathbf{9}$ & 7.50 & 6.88 & 5.75 & 4.13 & 44.9 \\
\hline $\mathbf{1 2}$ & 8.13 & 7.63 & 6.75 & 3.70 & 54.5 \\
\hline $\mathbf{1 5}$ & 9.38 & 8.00 & 7.00 & 5.38 & 42.6 \\
\hline $\mathbf{1 8}$ & 9.63 & 8.88 & 7.63 & 6.38 & 33.7 \\
\hline $\mathbf{2 1}$ & 10.13 & 9.74 & 6.80 & 3.88 & 61.7 \\
\hline $\mathbf{2 4}$ & 12.13 & 9.63 & 8.13 & 6.38 & 47.4 \\
\hline
\end{tabular}

Table. 4 Content of $\mathrm{Ca}+\mathrm{Mg}$ in the supernatant solution (ppm) during purification of humic acid from press mud at 24 hours of extraction

\begin{tabular}{|c|c|c|c|c|c|}
\hline $\begin{array}{c}\text { At 24 hours of } \\
\text { extraction }\end{array}$ & \multicolumn{5}{|c|}{ Ca+Mg content (ppm) } \\
\hline $\begin{array}{c}\text { Fractionation } \\
\text { periods( hrs) }\end{array}$ & $\begin{array}{c}\mathbf{1}^{\text {st }} \\
\text { wash }\end{array}$ & $\begin{array}{c}\mathbf{2}^{\text {nd }} \\
\text { wash }\end{array}$ & $\begin{array}{c}\mathbf{3}^{\text {rd }} \\
\text { wash }\end{array}$ & $\mathbf{4}^{\text {th }}$ wash & $\begin{array}{c}\text { \% decrease in content in } \mathbf{4}^{\text {th }} \\
\text { st } \\
\text { wash over 1 }\end{array}$ \\
\hline $\mathbf{3}$ & 15.2 & 13.6 & 10.4 & 8.8 & 42.1 \\
\hline $\mathbf{6}$ & 13.6 & 12 & 8.4 & 6 & 55.9 \\
\hline $\mathbf{9}$ & 13.2 & 11.6 & 10.32 & 7.6 & 42.4 \\
\hline $\mathbf{1 2}$ & 14.4 & 10.8 & 9.6 & 7.6 & 47.2 \\
\hline $\mathbf{1 5}$ & 14.4 & 12 & 9.6 & 7.2 & 50.0 \\
\hline $\mathbf{1 8}$ & 14 & 11.2 & 9.2 & 6.4 & 54.3 \\
\hline $\mathbf{2 1}$ & 15.6 & 12.8 & 11.2 & 8.8 & 43.6 \\
\hline $\mathbf{2 4}$ & 16 & 11.6 & 11.2 & 7.2 & 55.0 \\
\hline
\end{tabular}




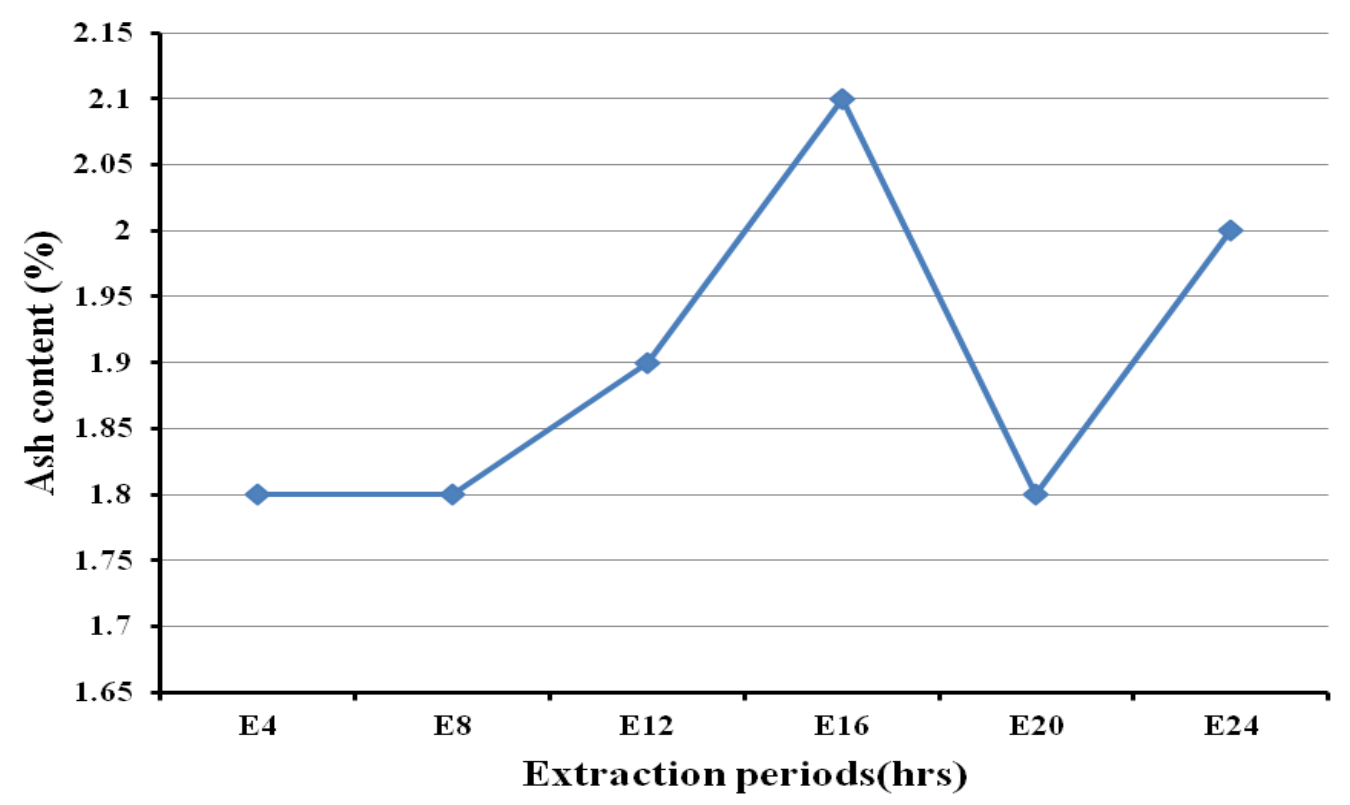

Fig.1 Effect of extraction periods on ash content derived from press mud

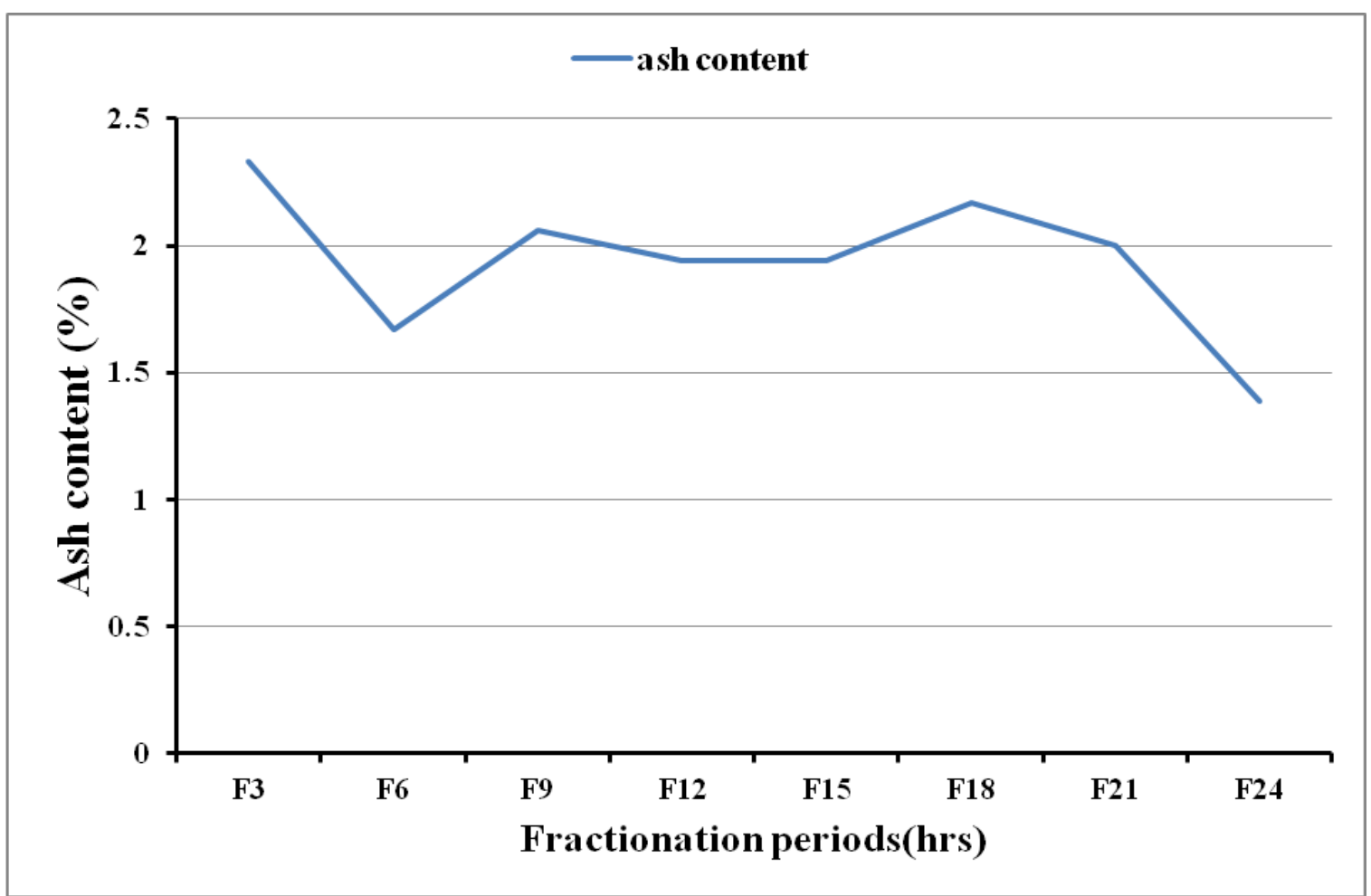

Fig.2 Effect of fractionation periods on ash content derived from press mud 
Interaction effect of extraction and fractionation periods

Among the interactions of fractionation and extraction periods, the ash content varied from 1.0 to 2.67 per cent when water was used as a purifying agent. On the other hand, when $\mathrm{HCl}-\mathrm{HF}$ mixture was used for purification of HA; the ash content of HA vary from 1.0 per cent ( 24 hours of extraction and 24 hours fractionation) to 1.50 per cent (12 hours of extraction \& 12 hours of fractionation). From the earlier review, it is known that the permissible limit of ash content in the HA is about 2 per cent. Hence, it is noteworthy to mention here that use of $\mathrm{HCl}$ and $\mathrm{HF}$ mixture, as per standard procedure, in the purification process can be eliminated and distilled water alone can be used as a purifying agent so as to bring ash content below 2 per cent.

Potassium, sodium and $\mathrm{Ca}+\mathrm{Mg}$ content in the supernatant solution during purification process (at 24 hours of extraction periods along with different fractionation periods).

The HA generated from press mud at 24 hours of extraction and different fractionation periods was subjected to further purification process with distilled water to reduce the content of inorganic ions. At 24 hours of extraction periods, as the equilibrium time increased, generally the content of $\mathrm{K}, \mathrm{Na}$ and $\mathrm{Ca}+\mathrm{Mg}$ in the supernatant solution also increased. Secondly, in a particular fractionation period, removal of $\mathrm{K}, \mathrm{Na}$ and $\mathrm{Ca}+\mathrm{Mg}$ was found to be higher in the $4^{\text {th }}$ washing compared to $1^{\text {st }}$ washing. At 24 hours of fractionation and 24 hours of extraction, the removal of $\mathrm{K}, \mathrm{Na}$ and $\mathrm{Ca}+\mathrm{Mg}$ in the $4^{\text {th }}$ washing over $1^{\text {st }}$ washing of HA was 40.9 per cent in K, 47.4 per cent in $\mathrm{Na}$ as well as 55.0 per cent in $\mathrm{Ca}+\mathrm{Mg}$ ( Table 2 - 4).
When HA was extracted they were not free from mineral matter. The relatively low content of inorganic ions in the purified HA may be ascribed to washing during the purification. Washing of the HA with distilled water consistently reduced the contents of inorganic ions. The concentrations of $\mathrm{K}, \mathrm{Ca}$, $\mathrm{Mg}$ and $\mathrm{Na}$ at first washing were generally high but the concentrations of these elements decreased remarkably indicating increase in the contents of $\mathrm{K}, \mathrm{Ca}, \mathrm{Mg}$ and $\mathrm{Na}$ following purification (using distilled water). Similar findings were also reported by Ahmed et al., (2004) for HA isolated from composted pineapple leaves and Susilawati, et al., (2007).

Apart from removal of basic cations during washing with distilled water, it has the ability to serve as Bronsted-Lowry acid thereby donating more $\mathrm{H}^{+}$ion which might have replaced some of left over $\mathrm{K}^{+,} \mathrm{Na}^{+}$and $\mathrm{Ca}+\mathrm{Mg}$ from the exchange sites of the HA which were perhaps not replaced by $\mathrm{H}^{+}$ (during acidification) during the fractionation process. Similar findings have also been reported by Kakezawa et al., (1992) and Ahmed (2005).

Humic acids isolated from press mud can be purified within one hour using distilled without altering the true nature of HA. The low ash content of the humic acid suggested that humic acid contained fewer amounts of inorganic ions and purification process is effective in reducing the mineral matter. During the process of purification of humic acid with distilled water, content of $\mathrm{K}, \mathrm{Na}$ and $\mathrm{Ca}+\mathrm{Mg}$ in the supernatant solution decreased considerably from $1^{\text {st }}$ wash to $4^{\text {th }}$ wash. It indicated that the $\mathrm{H}^{+}$ion of the distilled water has effectively replaced some of the remaining $\mathrm{K}, \mathrm{Na}$ and $\mathrm{Ca}+\mathrm{Mg}$ ions from exchange sites of the humic acid which are not replaced during fractionation process. 


\section{References}

Ahmed, O. H., Husni, M. H. A., Anuar, A. R. and Hanafi, M. M., 2005, Effects of extraction and fractionation time on the yield of compost humic acids. N.Z.J. Crop Hortic. Sci., 33: 107-110.

Ahmed, O. H., Husni, M. H. A., Anuar, A. R., Hanafi, M. M. and Angela, E. D. S., 2004, A modified way of producing humic acid from composted pineapple leaves. J. Sustainable Agric., 25(1): 129-139.

Hesse, P. R., 1994, Textbook of Soil Chemical Analysis. pp: 35

Jackson, M. L., 1973, Soil Chemical Analysis. Prentice Hall of India Pvt. Ltd., New
Delhi, pp. 498.

Kakezawa, M., Nishida, T. and Takahara, Y., 1992, Structural characteristics of humic acids extracted from woody composts by two-step composting process. Soil Sci., Plant Nutrition 38(1): 85-92.

Stevenson, F. J., 1994, Humus Chemistry: Genesis, Composition and Reactions, $2^{\text {nd }}$ Edn. John Wiley and Sons, New York, pp: 378-486.

Susilawati, K., Ahmed, O. H., Muhamad, A. B. N. and Khanif, M. Y., 2007, Effects of extraction and fractionation period on the yield of a tropical peat soil (Hemists) humic acids. Am. J. Agric. Biol. Sci. 2(3): 202-205.

\section{How to cite this article:}

Shreelatha, S. N. Bhat, S.R. Balanagoudar, R.V. Beladhadi, Satyanarayana Rao and M.V. Ravi. 2020. Simple Method of Purification of Humic Acid isolated from Press mud. Int.J.Curr.Microbiol.App.Sci. 9(01): 2070-2076. doi: https://doi.org/10.20546/ijcmas.2020.901.235 